\title{
Biohydrogen Production Using Immobilized Cells of Hyperthermophilic Eubacterium Thermotoga neapolitana on Porous Glass Beads
}

\author{
Tien Anh $\mathrm{Ngo}^{\mathrm{a}, \mathrm{b},{ }^{*}}$ and Ha Thi Viet Buib \\ ${ }^{a}$ Institute of Advanced Energy, Kyoto University, Uji, Kyoto 611-0011, Japan \\ ${ }^{b}$ Department of Microbiology, Hanoi University of Science, Hanoi, Vietnam
}

\begin{abstract}
Biohydrogen fermentation using immobilized cells of Thermotoga neapolitana on porous glass beads was successfully performed in a continuously stirring anaerobic bioreactor (CSABR) system operated under the conditions of temperature $75{ }^{\circ} \mathrm{C}, \mathrm{pH} 7.0$ and $5.0 \mathrm{~g} / \mathrm{L}$ pentose (xylose) and/or hexose (glucose). The results showed that both batch and fed-batch cultivations of the immobilized cells were effective for high-rate and high-yield $\mathrm{H}_{2}$ production compared with those from the free cells. In the batch cultivation, the $\mathrm{H}_{2}$ production rate and $\mathrm{H}_{2}$ production yield of the immobilized cells, respectively achieved the highest values of $5.64 \pm 0.19 \mathrm{mmol}^{-} \mathrm{H}_{2} \mathrm{~L}^{-1} \mathrm{~h}^{-1}$ and $1.84 \pm 0.1 \mathrm{~mol} \mathrm{H}_{2} / \mathrm{mol}^{\mathrm{x}}$ xylose, which were almost 1.7-fold and 1.3-fold higher than those with free cells. The maximum $\mathrm{H}_{2}$ production rate $\left(6.91 \mathrm{mmol} \mathrm{L}^{-1} \mathrm{~h}^{-1}\right)$ in this proposed method was 1.5 -fold higher than that of free cells in the fed-batch cultivation.
\end{abstract}

Keywords: Thermotoga neapolitana, Biohydrogen, Immobilized cells, Porous glass beads, CSABR, Fed-batch culture.

\section{INTRODUCTION}

Nowadays, many research efforts have been devoted to the sustainable and alternative energy, which is of critical importance with the ever-growing energy demands and climate change concerns, together with the fossil fuel depletion [1, 2]. Biohydrogen is an ideal, clean and friendly energy source that does not produce environmental pollution as carbon dioxide [3]. Furthermore, it can be produced from various renewable resources, which might be derived from pure sugars (glucose and xylose) [4, 5], agricultural residues, woody biomass [6-8] and biodiesel industry (glycerol waste) [9, 10], via biological conversion. Therefore, fermentative biohydrogen production technology has developed rapidly and considered as a promising treatment technology for organic wastes with efficient clean bioenergy production $[11,12]$.

The hypertheromophilic bacteria Thermotoga have garnered increasing interest for potential biohydrogen generation because of its high yields from a wide range of carbohydrates, such as glucose, sucrose, xylose, glycerol [5, 9, 13-21], and even rice straw [22]. Moreover, the optimum growth temperature of Thermotoga at an ambient $75^{\circ} \mathrm{C}$ makes its $\mathrm{H}_{2}$ fermentation less sensitive to contamination from methanogenic archaea, with a higher rate of hydrolysis and $\mathrm{H}_{2}$ yield [23-26].

*Address correspondence to this author at the Institute of Advanced Energy, Kyoto University, Uji, Kyoto 611-0011, Japan; Tel: 81774383512

Fax: 8177438 3516; E-mail: ngo@iae.kyoto-u.ac.jp
Many researchers have examined various methods for efficient biohydrogen production with $T$. neapolitana. The optimization of cultivation conditions such as temperature, $\mathrm{pH}$, initial concentration of substrate (carbon and nitrogen source), and ratio of medium volume were studied in small batch cultivation for efficient $\mathrm{H}_{2}$ production of $T$. neapolitana [23]. $\mathrm{N}_{2}$ sparging was a useful technique to enhance the $\mathrm{H}_{2}$ yield of strictly anaerobically fermentative bacterium $T$. neapolitana $[4,9]$. In recent years, the immobilized cell systems have become popular alternatives over freecell systems because they are capable of maintaining higher biomass concentrations and operating at higher dilution rates without biomass washout [27]. However, the $\mathrm{H}_{2}$ production based on immobilized-cell systems has mainly focused on using mesophilic bacteria such as porous glass beads-immobilized growing cells of Clostridium butyricum [28, 29a], agar gels-immobilized cells of Rhodospirillum rubrum [30], agar gels/porous glass beads-immobilized cells of aciduric Enterobacter aerogenes HO-39 [29b], lignocellulosic materialssupported Enterobacter cloacae IIT-BT08 [27], immobilized sewage sludge [31, 32], polydimethylsiloxane-immobilized microbial consortia [33], and so on. To the best of our knowledge, until now, there has been no research on enhanced $\mathrm{H}_{2}$ production using immobilized cells of $T$. neapolitana on porous glass bead. Even though, the $\mathrm{H}_{2}$ production using immobilized cells of $T$. neapolitana on acrylic hydrogel with $\mathrm{pH}$-buffering properties was investigated on single report [36]. However, the $\mathrm{H}_{2}$ production rate and $\mathrm{H}_{2}$ production yield in batch culture were less than those with free cells [36]. 
In this study, immobilized cell systems and suspended cell systems using $T$. neapolitana were studied and compared based on $\mathrm{H}_{2}$ production. This is the first report on the performance of immobilized cells T. neapolitana on porous glass beads for high-rate $\mathrm{H}_{2}$ production. Hydrogen production rate, hydrogen content in biogas, soluble metabolites compositions and hydrogen yield were examined. The Fed-batch cultivation at constant $\mathrm{pH}$ was conducted for preventing substrate-associated growth inhibition by controlling the nutrient supply.

\section{MATERIALS AND METHODS}

\subsection{Strain and Cultivation Medium}

Thermotoga neapolitana strain DSM 4359 was obtained from Deutsche Sammlung von Mikroorganismen und Zelhulturen (Germany). The cultures was grown in modified Thermotoga maritima basal culture medium (TMB) at $75{ }^{\circ} \mathrm{C}$ and $\mathrm{pH} 7.5$, with $10 \%$ $(\mathrm{v} / \mathrm{v})$ inoculation [23]. The medium used for $\mathrm{H}_{2}$ fermentation consisted of (amounts are in grams per liter of deionised water): $1.5 \quad \mathrm{~g} \mathrm{KH}_{2} \mathrm{PO}_{4} ; 4.2 \mathrm{~g}$ $\mathrm{Na}_{2} \mathrm{HPO}_{4} 12 \mathrm{H}_{2} \mathrm{O}\left(22 \mathrm{mM} \mathrm{PO}{ }^{3-}\right) ; 0.5 \mathrm{~g} \mathrm{NH}_{4} \mathrm{Cl} ; 0.2 \mathrm{~g}$ $\mathrm{MgCl}_{2} 6 \mathrm{H}_{2} \mathrm{O}$ (1.0 mM); $20.0 \mathrm{~g} \mathrm{NaCl} ; 2.0 \mathrm{~g}$ yeast extract; $5.0 \mathrm{~g}$ carbon source (glucose, xylose); $15.0 \mathrm{~mL}$ of the trace element solution (DSM-TES, see DSMZ medium 141); and $1.0 \mathrm{mg}$ resazurin, which was used as a redox indicator. The anaerobic conditions for growth were created by adding $1.1 \mathrm{~g}$ cysteine hydrochloride as a reducing agent and flushing the headspace of the serum bottles with pure $\mathrm{N}_{2}$ within 5 min.

\subsection{Small Batch Cultivation by Immobilized Cells on Porous Glass Beads}

Porous glass beads, vitralPOR (about $4 \mathrm{~mm}$ in diameter, 60-300 $\mu \mathrm{m}$ in pore size) were purchased from ROBU Glassfilter-Geräte $\mathrm{GmbH}$ Co., Schützenstrasse, Hattert, Germany. $25 \mathrm{~mL}$ of porous glass beads, $4 \mathrm{~mL}$ of precultured broth of the bacterium and $50 \mathrm{~mL}$ basal culture medium were put in a $120 \mathrm{~mL}$ serum bottle. Gas phase in upper layer was replaced with nitrogen gas and anaerobic batch cultivation was done at $75^{\circ} \mathrm{C}$ and $\mathrm{pH} 7.5$.

\subsection{Hydrogen Production from the CSABR System}

During immobilizing $T$. neapolitana cells on porous glass bead, a batch cultivation using a $3 \mathrm{~L}$ bioreactor (Biotron, Korea) and charged with $300 \mathrm{~mL}$ of porous glass beads, $900 \mathrm{~mL}$ of fresh medium and a $100 \mathrm{~mL}$ inoculum of $T$. neapolitana, was performed under constant temperature, $\mathrm{pH}$ and agitation at $75{ }^{\circ} \mathrm{C}, 7.0$ and $300 \mathrm{rpm}$, respectively, using a Biotron controller system [5,34]. The $\mathrm{pH}$ was kept constant by addition of $2.0 \mathrm{~N} \mathrm{NaOH}$. The temperature was kept at $75^{\circ} \mathrm{C}$ using a heating coil wrapped around the bioreactor. The gas headspace was sparged with a continuous and pure $\mathrm{N}_{2}$ gas flow; the gas outlet from the reactor was connected to condenser. The flow and partial pressure of the gas headspace in the outlet gas were monitored by a gas meter. After the batch culture, a fed batch culture was started by feeding a fresh medium $(100 \mathrm{~mL})$. The feed medium was prepared in a stock solution of the substrate with $50 \mathrm{~g} \mathrm{~L}^{-1}$ xylose, $20 \mathrm{~g} \mathrm{~L}^{-1}$ yeast extract, cysteine- $\mathrm{HCl}$, salts, and the trace element solution in the concentration stated in session of strain and cultivation medium and adjusted to $\mathrm{pH} 7.0$ using $2.0 \mathrm{~N}$ $\mathrm{NaOH}$, which was added in four doses at a feed rate of $12 \mathrm{~mL}$ per min. The growth at $\mathrm{pH} 7.0$ was controlled during the fed-batch culture using $2.0 \mathrm{~N} \mathrm{NaOH}$. The complete setup is illustrated on Scheme 1 [5].

\subsection{Sampling and Analyses}

Scanning electron microscopy of the cells immobilized on porous glass beads was conducted using SEM with a JEOL JSM-7401F cold cathode field emission scanning electron microscope.

The methods for sampling, analyses as well as calculation of $\mathrm{H}_{2}$ production were described in our previous works $[5,34]$. Biomass concentration in free systems was monitored by dry cell weight (DCW). The $\mathrm{H}_{2}$ gas in the headspace was determined by a gas chromatograph (GC, Hewlett Packard 5890 Series II, USA) employing a thermal conductivity detector (TCD). Substrates (Glucose and xylose) as well as organic acids (acetic and lactic acids) were quantified using an HPLC system equipped with a reflective index detector (Agilent 1100, USA).

\section{RESULTS AND DISCUSSION}

\subsection{Hydrogen Production Using the Immobilized Cells in Small Batch Cultivation}

Hexose (glucose) and pentose (xylose) are the hydrolyzed products of lignocellulosic materials and they respectively account for $55-65 \%$ and $35-45 \%$ in the total mass [32]. These substrates were used for $\mathrm{H}_{2}$ production by $T$. neapolitana $[4,5,9,15,23,34]$. In this study, preliminary experiments showed that $\mathrm{H}_{2}$ production using immobilized cells of $T$. neapolitana on porous glass beads with glucose and xylose substrates 


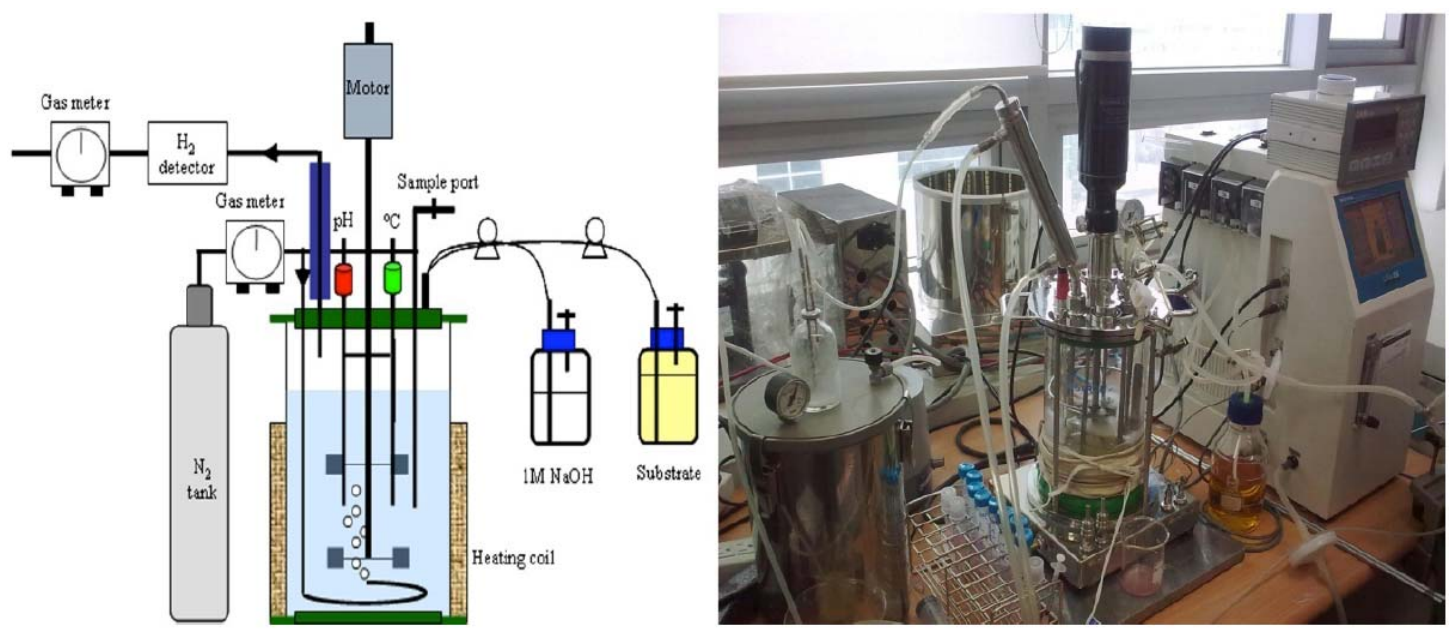

Scheme 1: Scheme of the anaerobic fermentation bioreactor used in the experiments.

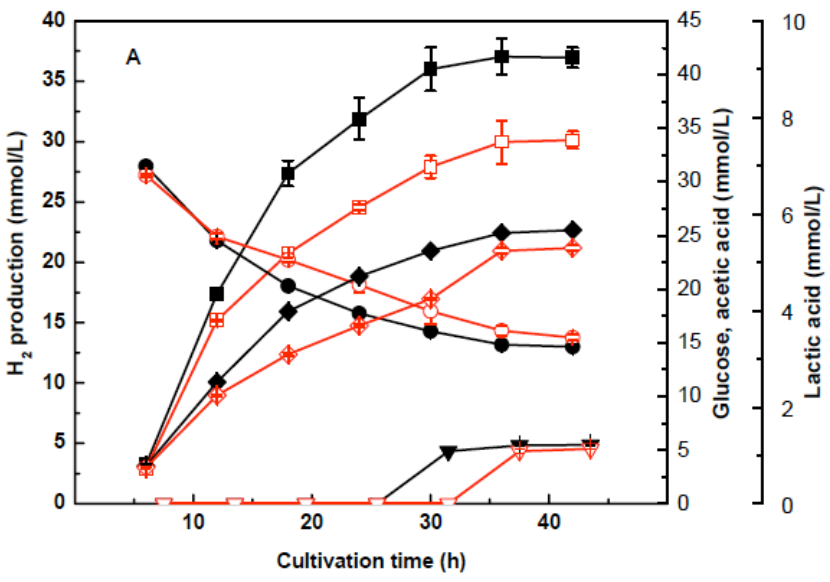

A

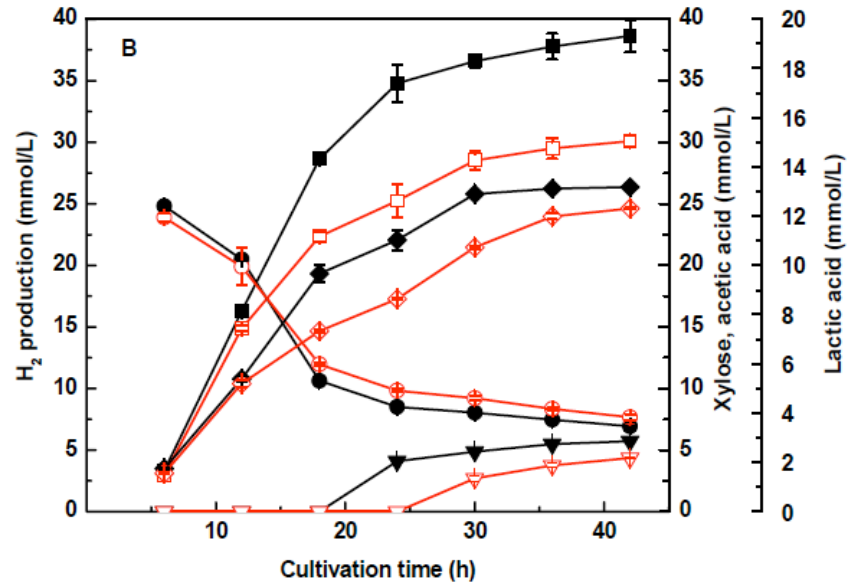

$\begin{array}{ll}\text { Free cells } \\ \square- & \mathrm{H}_{2} \text { production } \\ \square & \text { Residual substrate } \\ \square & \text { Acetic acid } \\ \square & \text { Lactic acid }\end{array}$

Immobilized cells

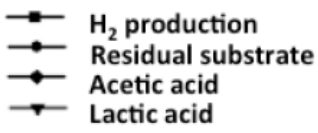

B

Figure 1: Metabolites of free cells and immobilized cells in serum bottles. All data are averages of three replicate bottles, \pm SEM: (A) glucose; (B) xylose.

was much higher than those free cell systems (Figure 1). It could be explained that the immobilized cell systems are capable of maintaining higher biomass concentrations and operating at higher dilution rates without biomass washout [27]. At the end of cultivation, the respective $\mathrm{H}_{2}$ production from glucose and xylose were $37 \pm 1.4\left(904 \pm 20 \mathrm{ml}^{-\mathrm{L}^{-1}}\right)$ and $38.6 \pm 1.3 \mathrm{mmol} . \mathrm{L}^{-1}$ $\left(944 \pm 32 \mathrm{ml}^{-\mathrm{L}^{-1}}\right)$, that were nearly 1.2 -fold greater for glucose and 1.3-fold greater for xylose than those of suspended cells with a maximum $\mathrm{H}_{2}$ production (30.1 \pm $0.7 \mathrm{mmol} . \mathrm{L}^{-1}$ for glucose and $30.1 \pm 0.4 \mathrm{mmol}^{-1}$ for xylose). Compared with the results from the highest previous report in the suspended cells system showed that a maximum $\mathrm{H}_{2}$ production (806 ml. $\mathrm{L}^{-1}$ for glucose and $625 \mathrm{ml}^{-1} \mathrm{~L}^{-1}$ for xylose [4]) was less than those with immobilized cells in this study. This result indicated efficiency of immobilized cells in $\mathrm{H}_{2}$ production from $T$. neapolitana. The substrate utilization and other products such as acetic acid and lactic acid, which were generated simultaneously with $\mathrm{H}_{2}$ production [4, $13,15]$, were also determined and compared between suspended cells and immobilized cells of $T$. neapolitana. Similar to the $\mathrm{H}_{2}$ production result, the levels of acetic acid and lactic acid from fermentation with immobilized cells were higher than those of the suspended cells for both glucose and xylose. The 


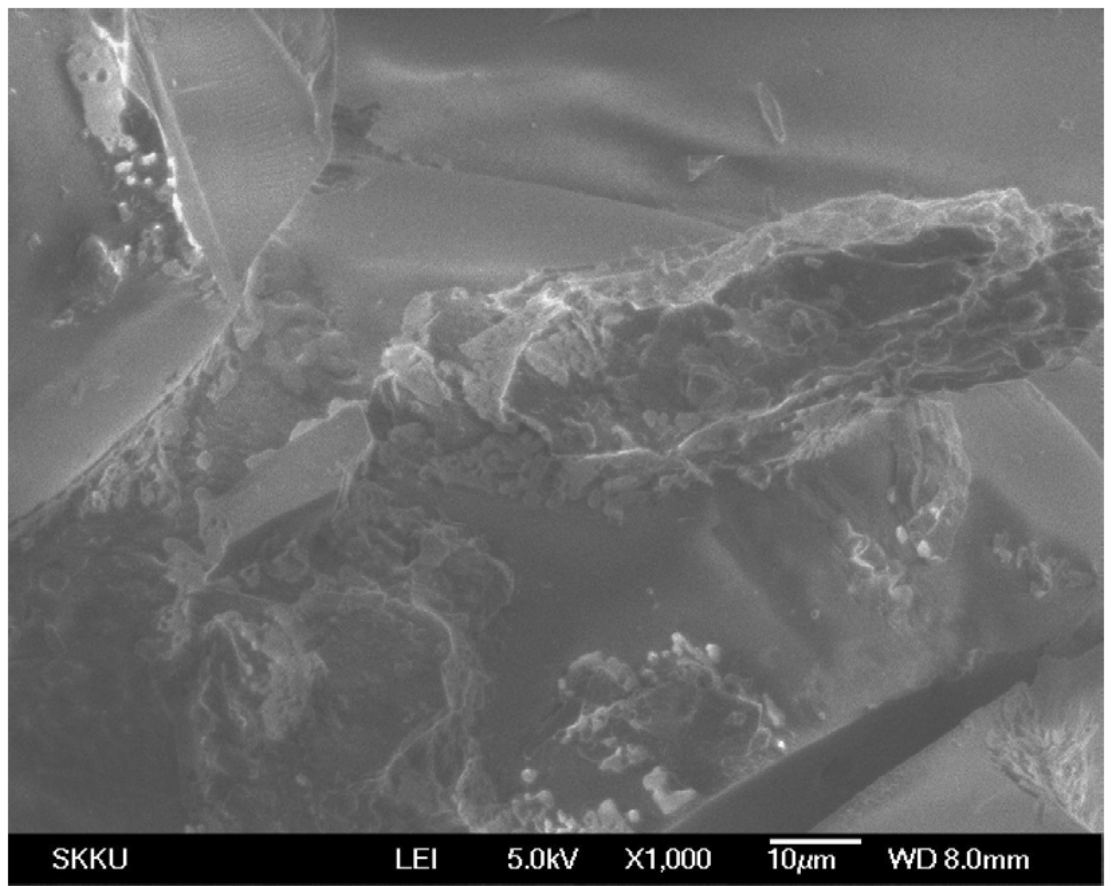

Figure 2: Scanning electron micrograph of the T. neapolitana immobilized on porous glass beads.

substrate utilization was observed to be faster in the immobilized cells compared to the suspended cells (Figure 1). A similar result was obtained from previous report [27-38]. Yokoi et al. (1997) found that $\mathrm{H}_{2}$ production and substrate consumption with immobilized cells of Clostridium butyricum on porous glass beads were higher than the corresponding values with free cells.

The scanning electron microscopy of immobilized cells on porous glass bead (Figure 2) showed that the bacterial cells were closely adsorbed to the bead pores. This allowed the substrates to be supplied readily to the bacteria and hydrogen and other gasses dissolved in culture broth would exit easily from the pores [29b].

\subsection{Hydrogen Production Using the Immobilized Cells in the $3 \mathrm{~L} \mathrm{CSABR}$}

The growth and $\mathrm{H}_{2}$ production of $T$. neapolitana in batch cultivation have been reported limited by a rapid decrease in $\mathrm{pH}$ and affective from high hydrogen partial pressure [4, 9]. To overcome this problem, both the immobilized cells and suspended cells were conducted in $\mathrm{pH}$-controlled batch bioreactors using a continuously stirring anaerobic bioreactor system at a constant $\mathrm{pH}$ of 7.0 (which was optimized in previous report [5]) and xylose as the main substrate. Results in Figure 3 and Table 1 showed that the best $\mathrm{H}_{2}$ production rate, $\mathrm{H}_{2}$ yield and acetic acid production in $\mathrm{pH}$-controlled cultivation with the immobilized cells were much higher than those suspended cells. In the immobilized cells system, the $\mathrm{H}_{2}$ production rate and accumulated $\mathrm{H}_{2}$ production were respectively achieved the highest values of $5.64 \pm 0.19 \mathrm{mmol}-\mathrm{H}_{2} \mathrm{~L}^{-1} \cdot \mathrm{h}^{-1}\left(138 \pm 5 \mathrm{ml}-\mathrm{H}_{2} \mathrm{~L}\right.$ ${ }^{1} \cdot \mathrm{h}^{-1}$ ) and $52.9 \pm 2.6 \mathrm{mmol}$. $\mathrm{L}^{-1}$. Respectively, these values were almost 1.7-fold and 1.4-fold higher than those suspended cells $\left(\mathrm{H}_{2}\right.$ production rate of $3.3 \pm 0.1$ mmol- $\mathrm{H}_{2} \mathrm{~L}^{-1} \cdot \mathrm{h}^{-1}$ and accumulated $\mathrm{H}_{2}$ production of 37.1 $\pm 1.8 \mathrm{mmol}$. $\mathrm{L}^{-1}$ ) (Figure $3 \mathrm{~B}$ and Table 1 ). This value also indicated a higher (3.5-fold) value than that of the immobilized cells on an acrylic hydrogel with $\mathrm{pH}$ buffering properties $\left(39.8 \pm 2.1 \mathrm{ml}-\mathrm{H}_{2} \cdot \mathrm{L}^{-1} \cdot \mathrm{h}^{-1}\right)$ [36]. An optimum $\mathrm{H}_{2}$ production was achieved with acetic acid as the main fermentative end-product [35]. In the present study, the acetic acid generation was measured in both the immobilized cells and free cells systems. Figure 3 showed that the amount of acetic acid production $\left(53 \pm 2.7 \mathrm{mmol} . \mathrm{L}^{-1}\right)$ with the immobilized cells at the end of cultivation was higher by approximately $80 \%$ comparing with the suspended cells $\left(29.5 \pm 1.5 \mathrm{mmol} \mathrm{L}^{-1}\right)$. The xylose consumption ratio versus cultivation time was shown in Figure 3 to compare the hydrogen-producing properties of the suspended cells and the immobilized cells in the CSABR. The xylose in the medium was completely consumed in the immobilized cells after $18 \mathrm{~h}$ of cultivation, while the suspended cells did not completely use xylose ( $80 \%$ of xylose consumption). In case of glucose as main substrate, Basile et al., 2012 
Table 1: Performance and Metabolites in Hydrogen Fermentation of T. neapolitana in Batch Mode System

\begin{tabular}{|c|c|c|}
\hline \multirow{2}{*}{ Parameters } & \multicolumn{2}{|c|}{ Working volume of $1 \mathrm{~L}$ in a $3 \mathrm{~L}$ CSABR system } \\
\hline & Free cells & Immobilized cells \\
\hline Maximum $\mathrm{H}_{2}$ content (\%) & $33.4 \pm 1.6$ & $43.1 \pm 1.98$ \\
\hline Maximum $\mathrm{H}_{2}$ production rate $\left(\mathrm{mmol}-\mathrm{H}_{2} \mathrm{~h}^{-1}\right)$ & $3.3 \pm 0.1$ & $5.64 \pm 0.19$ \\
\hline $\mathrm{H}_{2}$ yield $^{* * *}$ & $1.42 \pm 0.09$ & $1.84 \pm 0.1$ \\
\hline Final acetic acid $\left(\mathrm{g} \mathrm{L}^{-1}\right)$ & $1.77 \pm 0.1$ & $3.19 \pm 0.15$ \\
\hline Final lactic acid $\left(\mathrm{g} \mathrm{L}^{-1}\right)$ & nd" & nd \\
\hline Xylose consumption (\%) & $80.1 \pm 4.5$ & $99.9 \pm 1.1$ \\
\hline Final $\mathrm{pH}$ & 7.0 & 7.0 \\
\hline
\end{tabular}

Each measurement was repeated three times and averaged. The cultivation was at $75^{\circ} \mathrm{C}, \mathrm{pH} 7.0$ with $5.0 \mathrm{~g} / \mathrm{L}$ of initial concentration of substrate (xylose). "CSABR = continuously stirred anaerobic bioreactor.

nd $=$ not detected

${ }^{* * *} \mathrm{H}_{2}$ yield $=\left(\mathrm{H}_{2}\right.$ formed, mol)/ (substrate consumed, mol).

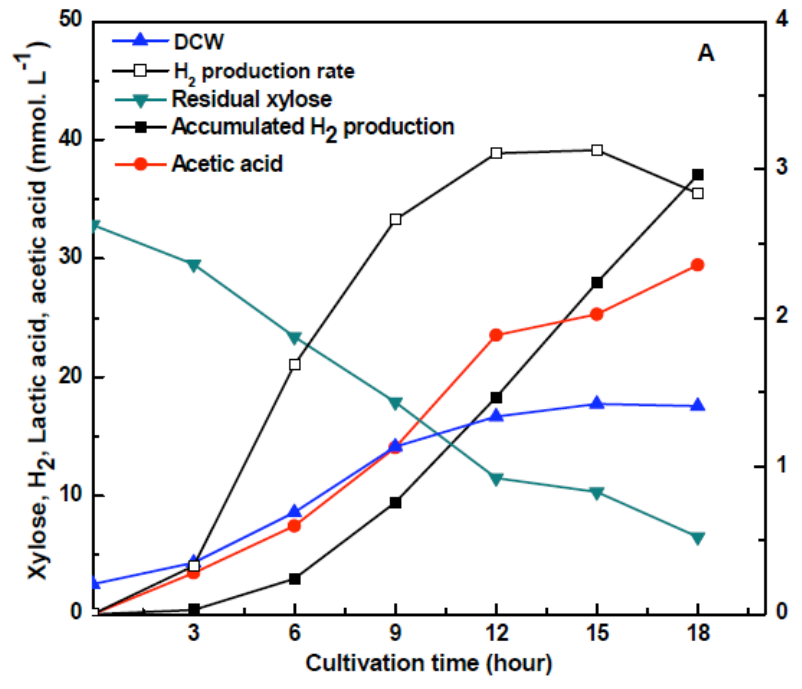

A

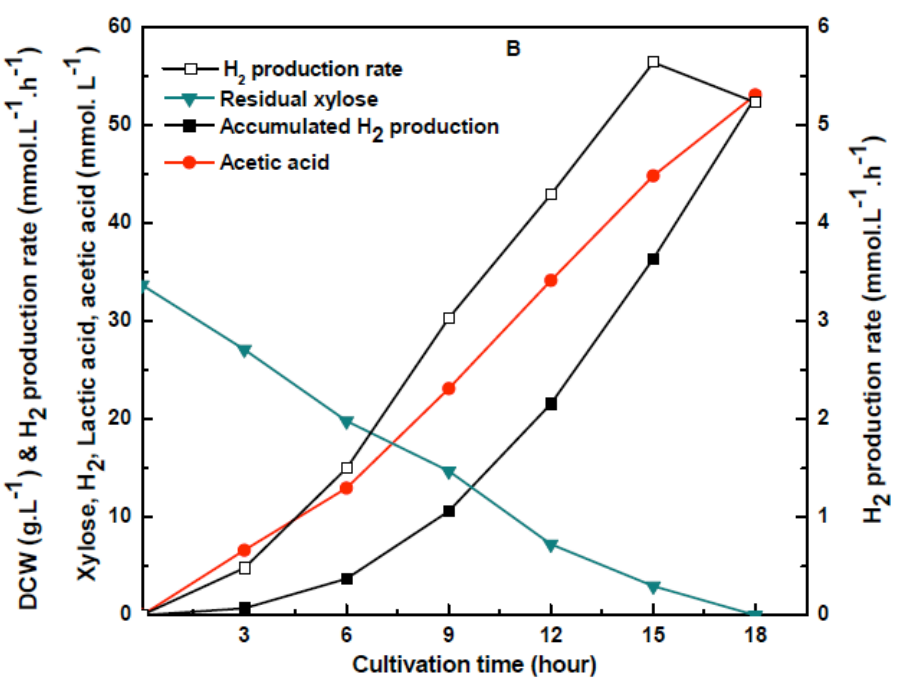

B

Figure 3: Growth of T. neapolitana on xylose substrate in the batch cultivation using a 3 L-CSABR: (A) Free cells, (B) Immobilized cells.

reported that glucose consumption was $50 \%$ and $75 \%$ for the suspended cells and the immobilized cells of $T$. neapolitana on an acrylic hydrogel after $21 \mathrm{~h}$ of cultivation, respectively [36]. These results strongly confirmed that the immobilized cells of $T$. neapolitana on porous glass beads are effective for high rate and yield $\mathrm{H}_{2}$ production compared to the system of the free cells or immobilized cells of $T$. neapolitana on an acrylic hydrogel.

\subsection{Hydrogen Production Using the Immobilized Cells in Fed-Batch Cultivation}

To develop a large-scale $\mathrm{H}_{2}$ production system as well as preventing substrate-associated growth inhibition when use the immobilized cells of $T$. neapolitana, $\mathrm{pH}$-controlled fed-batch cultivation with xylose substrate doses was carried out by controlling the nutrient supply. To compare the hydrogenproducing properties between the suspended cells and the immobilized cells, fed-batch cultivation in a $3 \mathrm{~L}$ CSABR was conducted at the same condition with a constant $\mathrm{pH}$ of 7.0 and a concentrated fresh medium containing $5.0 \mathrm{~g} \mathrm{~L}^{-1}$ xylose.

The feeding time was determined according to the final xylose concentration. The initial xylose concentration was $5.0 \mathrm{~g} \mathrm{~L}^{-1}$. Figure $4 \mathrm{~B}$ showed the changes in xylose concentration after the concentrated fresh medium for $\mathrm{H}_{2}$ production was added into the system. Identical to the suspended cells system (data not shown here), $\mathrm{H}_{2}$ production occurred after a lag 


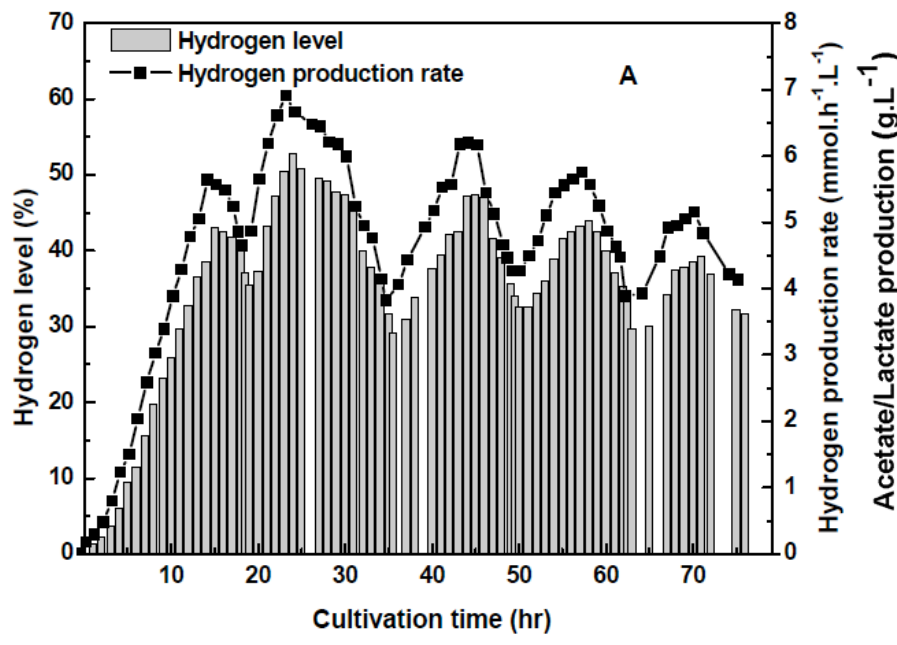

A

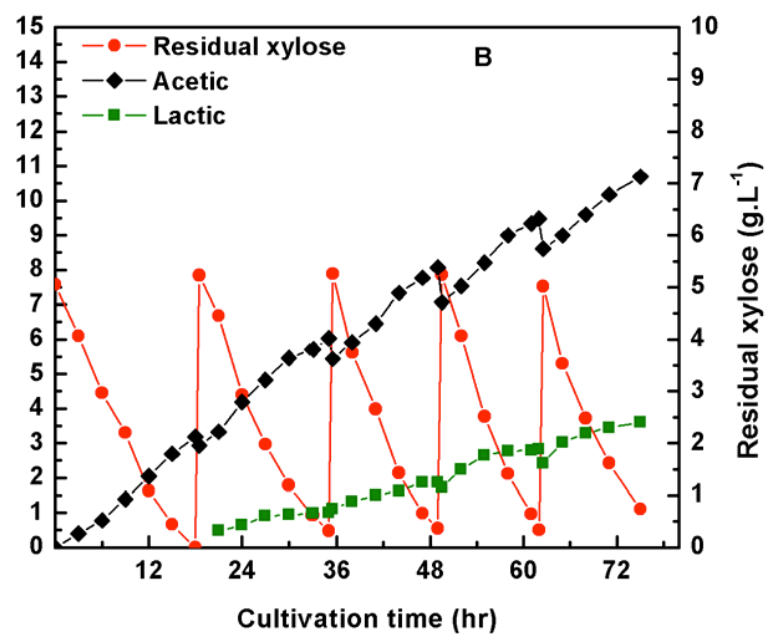

B

Figure 4: Growth and metabolite products of $T$. neapolitana in variable fed-batch cultivation with xylose substrate using the immobilized cells.

phase of approximately $6 \mathrm{~h}$. After $15 \mathrm{~h}$ fermentation, $\mathrm{H}_{2}$ production quickly reached to a maximum value with a maximum $\mathrm{H}_{2}$ gas content and the $\mathrm{H}_{2}$ production rate

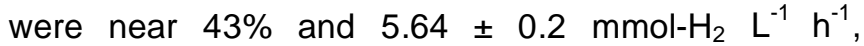
respectively (Figure 4A). After $18 \mathrm{~h}$, the $\mathrm{H}_{2}$ production rate dropped slowly to $5.2 \pm 0.26 \mathrm{mmol}^{-} \mathrm{H}_{2} \mathrm{~L}^{-1} \mathrm{~h}^{-1}$ with xylose being completely utilized (Figure 4B). The $\mathrm{H}_{2}$ production rate and substrate utilization in the immobilized cells were much higher comparing with the suspended cells $\left(3.02 \pm 0.15 \mathrm{mmol}-\mathrm{H}_{2} \mathrm{~L}^{-1} \mathrm{~h}^{-1}, 87.8 \%\right.$ xylose utilization) [5]. Along with determination of $\mathrm{H}_{2}$ production and substrate consumption, the acetic acid and lactic acid concentrations were measured and showed in Figure 4B. The acetic acid concentration increased according to the fermentation time and reached $3.2 \pm 0.16 \mathrm{~g} . \mathrm{L}^{-1}$ after $18 \mathrm{~h}$ cultivation. This value was higher than that of the free cells (approximately 1.5 g. $\mathrm{L}^{-1}$ ) $\quad$ [5]. No lactic acid concentration was determined after $18 \mathrm{~h}$ fermentation.

After $18 \mathrm{~h}$, the first fed-batch process started with concentrated fresh medium being immediately added to the system. The final respective xylose and biomass concentrations in the medium were $5.2 \pm 0.2{\mathrm{~g} . ~ \mathrm{~L}^{-1}}$ and $3.4 \pm 0.17 \mathrm{~g} \mathrm{DCW} \mathrm{L}^{-1}$ at 18 and $36 \mathrm{~h}$. Similar to the fedbatch cultivation of the free cells [5], the biomass concentration increased rapidly to a constant value of $4.9 \pm 0.2$ to $5.1 \pm 0.2 \mathrm{~g} \mathrm{~L}^{-1}$ during $27-35 \mathrm{~h}$ with the substrate being almost entirely consumed (Figure 4B). In this phase, the maximum $\mathrm{H}_{2}$ production rate and $\mathrm{H}_{2}$

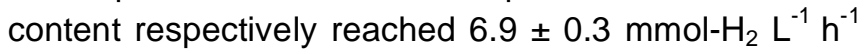
and approximately $53 \%$ at $24 \mathrm{~h}$ (Figure 4B). These values were almost 1.5 -fold and 1.1 fold higher than those of the free cells system $\left(4.62 \pm 0.23 \mathrm{mmol}^{-\mathrm{H}_{2} \mathrm{~L}^{-1}}\right.$ $\mathrm{h}^{-1}$ and $47 \%$, respectively) [5]. Lactic acid was determined at $21 \mathrm{~h}$. At the end of this phase, acetic acid and lactic acid concentrations were $6.0 \pm 0.3 \mathrm{~g} . \mathrm{L}^{-1}$ and $1.0 \pm 0.02 \mathrm{~g} . \mathrm{L}^{-1}$, respectively.

After $36 \mathrm{~h}$, the second fed-batch process began with adding concentrated fresh medium and giving a final

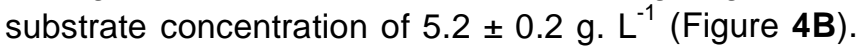
The $\mathrm{H}_{2}$ production rate and $\mathrm{H}_{2}$ content reached

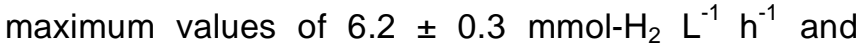
approximately $47 \%$ (Figure 4B), respectively. These values were much higher than those of the free cells

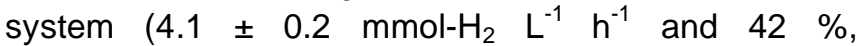
respectively) [5]. The $\mathrm{H}_{2}$ production rate then gradually decreased when the substrate was almost fully utilized. The acetic acid and lactic acid concentrations were 8.1 $\pm 0.4 \mathrm{~g} \mathrm{~L}^{-1}$ and $1.9 \pm 0.1 \mathrm{~g} \mathrm{~L}^{-1}$, respectively (Figure 4B).

At $49 \mathrm{~h}$, the concentrated fresh medium was added again with a final substrate concentration of $5.24 \pm 0.25$ $\mathrm{g} \mathrm{L}^{-1}$ (Figure 4B). The highest $\mathrm{H}_{2}$ content and $\mathrm{H}_{2}$

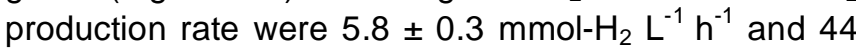
$\%$ (Figure 4B), respectively at $58 \mathrm{~h}$. These results were higher in comparison with a free cells system ( $3.9 \pm 0.2$ mmol- $\mathrm{H}_{2} \mathrm{~L}^{-1} \mathrm{~h}^{-1}$ and $40 \%$, respectively) [5]. At $62 \mathrm{~h}$, the xylose concentration was almost completely utilized. The respective with acetic acid and lactic acid concentrations of $9.5 \pm 0.44 \mathrm{~g} \mathrm{~L}^{-1}$ and $2.8 \pm 0.12 \mathrm{~g} \mathrm{~L}^{-1}$.

After $62 \mathrm{~h}$, fresh medium for hydrogen production was once again added with final xylose concentration of $5.0 \pm 0.2$ g. $\mathrm{L}^{-1}$ (Figure 4B). A maximum $\mathrm{H}_{2}$ production rate was achieved at $71 \mathrm{~h}$ (approximately $5.8 \pm 0.3 \mathrm{mmol}^{-} \mathrm{H}_{2} \mathrm{~L}^{-1} \mathrm{~h}^{-1}$ ) (Figure 4B). At the end of the fed-batch fermentation, the residual xylose, acetic acid, 
and lactic acid concentrations were $0.7 \pm 0.07 \mathrm{~g} \mathrm{~L}^{-1}$, $10.7 \pm 0.5 \mathrm{~g} \mathrm{~L}^{-1}$, and $3.6 \pm 0.18 \mathrm{~g} \mathrm{~L}^{-1}$, respectively.

The immobilized cells demonstrated a better hydrogen production in comparison to the free cells. The absorption capacity in the micro-porous structure of porous glass beads might play a role in improving hydrogen production rate and substrate utilization. Constant substrates supplied to bacteria cells which well adsorbed on beads allowed gas diffusion from pore. Therefore, T. neapolitana immobilized on porous glass beads in CSABR was effective for high-rate and high-yield $\mathrm{H}_{2}$ production comparing with those of the free cells. Similar results were obtained with immobilized C. butyricuman or E. Aerogenes HO-39 on porous glass beads (Yokoi et al., 1997), which gave high $\mathrm{H}_{2}$ production rate and yield. Aruna and Munawar 2012 reported an enhancement of photo $\mathrm{H}_{2}$ production by using alginate immobilized Rhodobacter sphaeroides $0 . \cup 5$ compared to the free cells [37]. In case of immobilized Clostridium sp. T2 on mycelia pellets in continuous stirred-tank reactor, the highest $\mathrm{H}_{2}$

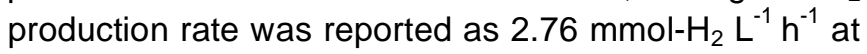
10 hydraulic retention time, which was $41 \%$ higher than the carrier-free process [38].

\section{CONCLUSIONS}

Biohydrogen fermentation using the immobilized cells of $T$. neapolitana on porous glass beads was performed successfully in a continuous stirring anaerobic bioreactor system. The hydrogen production in both the pH-controlled batch and fed-batch cultivation of the immobilized cells was higher than that of free cells system. The $\mathrm{H}_{2}$ production rate and accumulated $\mathrm{H}_{2}$ production of the immobilized cells reached highest values of $5.64 \pm 0.19 \mathrm{mmol} \mathrm{h}^{-1}$ and $52.9 \pm 2.6 \mathrm{mmol} \mathrm{L}^{-1}$, respectively, which were almost 1.7 -fold and 1.4-fold higher than those of free cells.

\section{ACKNOWLEDGEMENTS}

The authors express their sincere thanks to The Ministry of Science and Technology of Vietnam for funding the project (KC04.TN04/11-15). The authors also thank Dr. Huynh Van Ngoc for analysing SEM.

\section{REFERENCES}

[1] Rubin EM. Genomics of cellulosic biofuels. Nature 2008; 454: 841-45.

http://dx.doi.org/10.1038/nature07190

[2] Alper H, Stephanopoulos G. Engineering for biofuels: exploiting innate microbial capacity or importing biosynthetic potential? Nat Rev Microbiol 2009; 7: 715-23. http://dx.doi.org/10.1038/nrmicro2186
Winter CJ. Hydrogen energy- Abundant, efficient, clean: A debate over the energy-system-of-change. Int $\mathrm{J}$ Hydrogen Energy 2009; 34: S1-52. http://dx.doi.org/10.1016/j.ijhydene.2009.05.063

[4] Nguyen DTA, Han SJ, Kim JP, Kim MS, Sim SJ. Hydrogen production of the hyperthermophilic eubacterium, Thermotoga neapolitana under $\mathrm{N}_{2}$ sparging condition. Bioresour Technol 2010; 101: S38-S41.

http://dx.doi.org/10.1016/j.biortech.2009.03.041

[5] Ngo TA, Kim MS, Sim SJ. Thermophilic hydrogen fermentation using Thermotoga neapolitana DSM 4359 by fed-batch culture. Int J Hydrogen Energy 2011; 36: 1401423.

http://dx.doi.org/10.1016/j.ijhydene.2011.04.058

[6] Cheng CL, Lo YC, Lee KS, Lee DJ, Lin CY, Chang JS. Biohydrogen production from lignocellulosic feedstock. Bioresour Technol 2011; 102(18): 8514-23.

http://dx.doi.org/10.1016/i.biortech.2011.04.059

[7] Navarro RM, Sánchez-Sánchez MC, Alvarez-Galvan MC, Del Valle F, Fierro JLG. Hydrogen production from renewable sources: biomass and photocatalytic opportunities. Energy Environ Sci 2009; 2: 35-54.

\section{http://dx.doi.org/10.1039/b808138g}

[8] Qiu C, Wen J, Jia X. Extreme-thermophilic biohydrogen production from lignocellulosic bioethanol distillery wastewater with community analysis of hydrogen-producing microflora. Int J Hydrogen Energy 2011; 14: 8243-51. http://dx.doi.org/10.1016/j.ijhydene.2011.04.089

[9] Ngo TA, Kim MS, Sim SJ. High-yield biohydrogen production from biodiesel manufacturing waste by Thermotoga neapolitana. Int J Hydrogen Energy 2011; 36: 5636-42. http://dx.doi.org/10.1016/j.ijhydene.2010.11.057

[10] Sakai S, Yaishita T. Microbial production of hydrogen and ethanol from glycerol-containing wastes discharged from a biodiesel fuel production plant in a bioelectrochemical reactor with thionine. Biotechnol Bioeng 2007; 98(2): 340-48. http://dx.doi.org/10.1002/bit.21427

[11] Kalia V, Lal S, Ghai R, Manda M, Chauhan A. Mining genomic databases to identify novel hydrogen producers. Trends Biotechnol 2003; 21(4): 152-56.

http://dx.doi.org/10.1016/S0167-7799(03)00028-3

[12] Kapdan I, Kargi F. Bio-hydrogen production from waste materials. Enzyme Micobial Technol 2006; 38: 569-82. http://dx.doi.org/10.1016/..enzmictec.2005.09.015

[13] Schröder C, Selig M, Schönheit P. Glucose fermentation to acetate, $\mathrm{CO}_{2}$, and $\mathrm{H}_{2}$ in the anaerobic hyperthermophilic eubacterium Thermotoga maritima: involvement of the Embden-Meyerhof pathway. Arch Microbial 1994; 16: 46070.

[14] van Niel EWJ, Budde MAW, de Haas GG, van der Wal FJ, Claassen PAM, Stams AJM. Distinctive properties of high hydrogen producing extreme thermophiles, Caldicellulosiruptor saccharolyticus and Thermotoga elfii. Int J Hydrogen Energy 2002; 27: 1391-98.

http://dx.doi.org/10.1016/S0360-3199(02)00115-5

[15] d'Ippolito G, Dipasquala L, Vella FM, Romano I, Gambacorta A, Fontana A. Hydrogen metabolism in the extreme thermophile Thermotoga neapolitana. Int $\mathrm{J}$ Hydrog Energy 2010; 35: 2290-95.

http://dx.doi.org/10.1016/j.ijhydene.2009.12.044

[16] Heyndrickx M, Vansteenbeeck A, Vos Pd, Ley Ld. Hydrogen gas production from continuous fermentation of glucose in a minimal medium with Clostridium butyrieum LMG 1213tl. Syst Appl Microbiol 1986; 8: 239-44.

http://dx.doi.org/10.1016/S0723-2020(86)80087-X

[17] Taguchi F, Mizukami N, Hasegawa K, Saito-Taki T. Microbial conversion of arabinose and xylose to hydrogen by a newly isolated Clostridium sp. No. 2. Can J Microbiol 1994; 40: 228-33.

http://dx.doi.org/10.1139/m94-037 
[18] Tanisho S, Suzuki Y, Wakao N. Fermentative hydrogen evolution by Enterobacter aerogenes strain E82005. Int J Hydrogen Energy 1987; 12: 623-27. http://dx.doi.org/10.1016/0360-3199(87)90003-6

[19] Yokoi H, Saitu A, Uchida H, Hirose J, Hayashi S, Takashi Y. Microbial hydrogen production from sweet potato starch residue. J Biosci Bioeng 2001; 9: 58-63.

[20] Ueno $\mathrm{Y}$, Otsuka S, Morimoto M. Hydrogen production from industrial wastewater by anaerobic microflora in chemostat culture. J Ferment Bioeng 1996; 82: 194-97.

http://dx.doi.org/10.1016/0922-338X(96)85050-1

[21] Kumar N, Ghosh A, Das D. Redirection of biochemical pathways for the enhancement of $\mathrm{H}_{2}$ production by Enterobacter cloacae. Biotechnol Lett 2001; 23: 537-41. http://dx.doi.org/10.1023/A:1010334803961

[22] Nguyen DTA, Kim KR, Kim MS, Sim SJ. Thermophilic hydrogen fermentation from Korean rice straw by Thermotoga neapolitana. Int J Hydrogen Energy 2010; 35: 13392-98.

http://dx.doi.org/10.1016/j.ijhydene.2009.11.112

[23] Nguyen DTA, Kim JP, Kim MS, Oh YK, Sim SJ. Optimization of hydrogen production by hyperthermophilic eubacteria, Thermotoga maritima and Thermotoga neapolitana in batch fermentation. Int J Hydrogen Energy 2008; 33: 1483-88. http://dx.doi.org/10.1016/j.ijhydene.2007.09.033

[24] Van Groenestijn J, Hazewinkel J, Nienoord M, Bussmann P. Energy aspects of biological hydrogen production in high rate bioreactors operated in the thermophilic temperature range. Int J Hydrogen Energy 2001; 27: 1141-47. http://dx.doi.org/10.1016/S0360-3199(02)00096-4

[25] Lu J, Gavala H, Skiadas I, Mladenovska Z, Ahring B. Improving anaerobic sewage sludge digestion by implementation of a hyper-thermophilic prehydrolysis step. $J$ Environm Manag 2008; 88: 881-89. http://dx.doi.org/10.1016/i.jenvman.2007.04.020

[26] Kádár Z, de Vrije T, van Noorden G, Budde M, Szengyel Z, Réczey K, Claassen P. Yields from glucose, xylose, and paper sludge hydrolysate during hydrogen production by the extreme thermophile Caldicellulosiruptor saccharolyticus. Appl Biochem Biotechnol 2004; 114: 497-508. http://dx.doi.org/10.1385/ABAB:114:1-3:497

[27] Kumar N, Das D. Continuous hydrogen production by immobilized Enterobacter cloacae IIT-BT 08 using lignocellulosic materials as solid matrices. Enzyme Microb Technol 2001; 29: 280-87. http://dx.doi.org/10.1016/S0141-0229(01)00394-5

[28] Karube I, Urano N, Matsunaga T, Suzuki S. Hydrogen production from glucose by immobilized growing cells of Clostridium butyricum. Appl Microbiol Biotechnol 1982; 16: 5-9. http://dx.doi.org/10.1007/BF01008235
[29] a) Yokoi H, Maeda Y, Hirose J, Hayashi S, Takasaki Y. $\mathrm{H}_{2}$ production by immobilized cells of Clostridium butyricum on porous glass beads. Biotechnol Tech 1997; 11: 431-33. http://dx.doi.org/10.1023/A:1018429109020

b) Yokoi H, Tokushige T, Hirose J, Hayashi S, Takasaki Y. Hydrogen production by immobilized cells of aciduric Enterobacter aerogenes Strain HO-39. J Ferment Bioeng 1997; 83(5): 481-84 http://dx.doi.org/10.1016/S0922-338X(97)83006-1

[30] von Felten P, Zürrer H, Bachofen R. Production of molecular hydrogen with immobilized cells of Rhodospirillum rubrum. Appl Microbiol Biotechnol 1985; 23: 15-20. http://dx.doi.org/10.1007/BF02660112

[31] Wu SY, Lin CN, Chang JS, Lee KS, Lin PJ. Microbial hydrogen production with immobilized sewage Sludge. Biotechnoil Prog 2002; 18: 921-26.

http://dx.doi.org/10.1021/bp0200548

[32] Wu SY, Lin CY, Lee KS, Hung CH, Chang JS, Lin PJ, Chang FY. Dark fermentation hydrogen production from xylose in different bioreactors using sewage sludge microflora. Energy Fuels 2008; 22: 113-19.

http://dx.doi.org/10.1021/ef700286s

[33] Ismail I, Hassan MA, Rahman NAA, Soon CS. Effect of retention time on biohydrogen production by microbial consortia immobilized in polydimethylsiloxane. Afr J Biotechnol 2011; 10: 601-609.

[34] Ngo TA, Nguyen TH, Bui HTV. Thermophilic fermentative hydrogen production from xylose by Thermotoga neapolitana DSM 4359. Renewable Energy 2012; 37: 174-79. http://dx.doi.org/10.1016/j.renene.2011.06.015

[35] Kaushik N, Debarata D. Improvement of fermentative hydrogen production - various approaches. Appl Microbiol Biotechol 2004; 65: 520-29.

[36] Basile M. A, Carfagna C, Cerruti P, d Ayala G. G, Fontana A, Gambacorta A, Malinconico M, Dipasquale L. Continuous hydrogen production by immobilized cultures of Thermotoga neapolitana on an acrylic hydrogel with pH-buffering properties. RSC Adv 2012; 2: 3611-14.

[37] Aruna K, Munawar TM. Biological hydrogen production by using immobilized Rhodobacter sphaeroides $0 . \cup 5 . \mathrm{J}$. Microbiol Biotech Res 2012; 2(6): 906-12.

[38] Zhao L, Cao GL, Wang AJ, Guo WQ, Liu BF, Ren HY, et al. Enhanced bio-hydrogen production by immobilized Clostridium sp. T2 on a new biological carrier. Int J Hydrogen Energy 2012; 37: 162-66. http://dx.doi.org/10.1016/j.ijhydene.2011.09.103

\section{DOI: http://dx.doi.org/10.6000/1929-6002.2013.02.03.4}

(c) 2013 Ngo and Bui; Licensee Lifescience Global.

This is an open access article licensed under the terms of the Creative Commons Attribution Non-Commercial License (http://creativecommons.org/licenses/by-nc/3.0/) which permits unrestricted, non-commercial use, distribution and reproduction in any medium, provided the work is properly cited. 